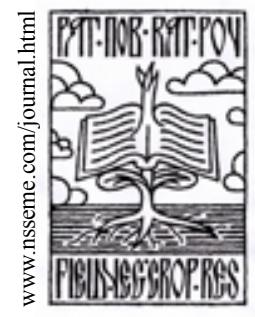

\title{
Cluster Analysis Technique for Assessing Variability in Cowpea (Vigna unguiculata L. Walp) Accessions from Nigeria
}

\author{
Abiola Toyin Ajayi • Adenubi I. Adesoye
}

\author{
received: 22 June 2013, accepted: 5 August 2013 \\ published online: 31 October 2013 \\ (c) 2013 IFVC \\ doi: $10.5937 /$ ratpov50-4069
}

\begin{abstract}
Summary: The genetic variability among 10 accessions of cowpea, Vigna unguiculata (L.) Walp was studied by the use of 13 qualitative and 13 quantitative traits. From the results on qualitative traits, dendrogram grouped the 10 accessions into two major clusters, 1 and 2.Cluster 1 had 3 accessions and cluster 2 had 2 sub-clusters (I and II), having 2 accessions in sub-cluster I and 5 accessions in sub-cluster II. The dendrogram revealed two major clusters, 1 and 2, for quantitative data, for the 10 accessions. At distance of 4 and 6, cluster 1 had two sub-clusters (I and II), with sub-cluster I having 5 accessions, sub-cluster II having 4 accessions while cluster 2 had only 1 accession. This study made the observation that identification of the right agro-morphological traits of high discriminating capacity is essential, before embarking on any genetic diversity; as it was revealed that some traits discriminated more efficiently among the accessions than others. A group of accessions, which are NGSA1, NGSA2, NGSA3, NGSA4, NGSA7, NGSA9 and NGSA10, was identified as being different from the others for number of seeds per pod, pod length, plant height, peduncle length, seed weight and number of pods per plant. These accessions may be good for cowpea improvement programs.
\end{abstract}

Key words: cluster analysis, clusters, cowpeas, dendrogram, traits, variability, Vigna

\section{Introduction}

Cowpea (Vigna unguiculata (L.) Walp) is an important crop adapted to the tropical and sub tropical regions of the world, where it serves as a source of protein for both urban and rural populations (Fawole et al.2006, Uarrotta 2010).It is one of the most widely cultivated and utilized grain legumes in Nigeria regarded as being affordable, with protein content of about $29 \%$ coupled with its potential to fix atmospheric nitrogen for soil improvement (Steele 1972, Adetiloye et al. 2013). International Institute of Tropical Agriculture (IITA) Gene Bank holds about 15,115 accessions of cowpea as a result of its mandate for cowpea improvement. In collaboration with regional and national research programs, IITA has developed many improved varieties expressing combination

A. T. Ajayi*

Adekunle Ajasin University, PMB 01, Akungba-Akoko, Ondo State, Nigeria

e-mail: ajayi.abiola.toyin@hotmail.com

A. I. Adesoye

Department of Botany, University of Ibadan, Ibadan, Nigeria of traits such as disease and insect resistance, early maturity, desired seed types, many of which have been distributed in over 65 countries (Fatokun et al. 2002). Yet, production of the crop is hindered by low grain yields, grain quality and susceptibility to diseases and pests, and lack of improved cultivars (Magloire 2005). The genetic improvement of the crop is limited due to inadequate knowledge of the genetic diversity of the existing germplasm. Breeding program for cowpea improvement has been a difficult task as a result of the crop being required on varietal basis in terms of many characters, which are region specific even though it is a single crop species (Magloire 2005).

Before any crop improvement program could be taken up, in any crop species, a thorough knowledge concerning the amount of genetic variability existing in that particular crop for various characters is important. Information on

\section{Acknowledgements:}

I am grateful to the National Centre for Genetic Resources and Biotechnology, (NACGRAB) Ibadan for providing the materials for this study. Moreover, my profound gratitude goes to Dr. O.F. Olotuah, and Dr. A.E. Gbadamosi of the Department of Plant Science and Biotechnology, Adekunle Ajasin University, Akungba-Akoko, Ondo State, Nigeria, for their technical support. 
nature and magnitude of variability in the existing plant material and association among the various characters is a pre-requisite for yield improvement (Vijayan 2005). Therefore, for successful plant breeding program, germplasm collection and diversity records are highly desirable (Magloire 2005, Knotova et al. 2010).

Morphological attributes have been extensively used to establish phylogenetic relationships between and within species and also for studying variability and correlated characters in cowpea. However, morphological traits are influenced by environmental factors, which may result in varying relationship patterns (Smith \& Smith 1989, Selvi et al. 2003), nevertheless they are still effective for selection (Magloire 2005). Quantitative and qualitative traits have been used by many researchers for different purposes in cowpea and related crops (Pasquet 1993, Obute 2001).

The role of cluster analysis as a tool for classifying varieties with similar attributes cannot be over emphasized as it has now become popular among researchers (Sabater 2004, Vural \& Karasu 2007). The objective of this study was to classify 10 accessions of cowpea into groups based on their qualitative and quantitative traits.

\section{Materials and Methods}

Ten indigenous accessions of cowpea used for this study were provided by the National Centre for Genetic Resources and Biotechnology (NACGRAB), Ibadan. These are part of collections maintained at NACGRAB, which are of Nigerian origin and locally grown by farmers. The accessions are NG/SA/DEC/07/0309, NG/ SA/07/1057, NGB/06/0055, NG/SA/07/0113, NG/SA/07/1066-1, NG/SA/07/0098, NG/AO/11/08/012, NG/SA/07/0063, $\mathrm{NGB} / 06 / 0057$ and NG/AO/11/08/0083; and coded for easy statistical analysis as NGSA1, NGSA2, NGSA3, NGSA4, NGSA5, NGSA6, NGSA7, NGSA8, NGSA9 and NGSA10 respectively. The experiment was conducted at the Experimental Field of the Department of Plant Science and Biotechnology, Adekunle Ajasin University, Akungba-Akoko, Ondo State, Nigeria (Latitude $7^{0} .28^{\prime} \mathrm{N}$, Longitude $5^{\circ} .44^{\prime} \mathrm{E}$, Altitude $423 \mathrm{~m}$ above sea level), during the raining season of 2012. The chemical properties of the soil and prevailing weather conditions during the period of the experiment are listed in Table 2 and Table 3, respectively. These 10 accessions were evaluated on a field laid out in a Randomized Complete Block Design with three replications. Each replicate consisted of 10 accessions, each of which was regarded as a treatment, and each treatment consisted of 20 plants, making the total number of plants on the field equal 600. Distance between rows and plants along a row were $50 \mathrm{~cm}$ and $30 \mathrm{~cm}$ respectively, with the planting depth being approximately $2.5 \mathrm{~cm}$. Weeding was done when required. A total of 10 plants were selected at random per treatment per replicate for data collection. Thirteen qualitative and thirteen quantitative traits were measured using the International Board for Plant Genetic Resources (IBPGR) cowpea descriptors. The qualitative traits are as shown in Table 1 . The quantitative traits measured: 100 -seed weight $(\mathrm{g})$, terminal leaflet length $(\mathrm{cm})$, terminal leaflet width $(\mathrm{cm})$, number of main branches, number of nodes on main stem, number of pods per peduncle, peduncle length $(\mathrm{cm})$, number of pods per plant, pod length $(\mathrm{cm})$, plant height $(\mathrm{cm})$, pod weight $(\mathrm{g})$, number of seeds per pod, and number of leaves per plant.

The data were subjected to cluster analysis using SPSS Window version (SPSS, Inc., Chicago IL).

\section{Results and Discussion}

For the 13 qualitative traits, 7 out of the 10 accessions had determinate growth pattern, while the remaining three were indeterminate. There were wide variations among the accessions for plant pigmentation; five (5) accessions were slightly pigmented, two (2) moderately pigmented, while the remaining three (3) were intermediate. Two (2) accessions had sub-globose terminal leaflet shape while the rest had sub-hastate. Three (3) accessions had straight pods while the rest had slight curved pods. Testa texture was smooth to rough for eight (8) accessions, while the rest had smooth testa. Leaf colour was intermediate for 6 accessions while the rest had dark green colour. All accessions were the same for flower colour, splitting of testa and plant hairiness. All accessions had only one variant for traits like immature pod pigmentation, seed shape and twinning tendency (Table 4). Highest level of variations for the quantitative traits was recorded for peduncle length $(\mathrm{cm}), 100$-seed weight $(\mathrm{g})$, terminal leaflet width $(\mathrm{cm})$, plant height $(\mathrm{cm})$ and pod weight (g) (Table 5).

Dendrogram grouped the 10 accessions into two major clusters; 1 and 2 , with result on qualitative traits, with cluster 1 having three (3) accessions and cluster 2, with 2 sub-clusters (I and II), having two (2) accessions in sub-cluster I and five (5) accessions in sub-cluster II (Figure 1). The dendrogram constructed based on the data from quantitative traits revealed two major clusters (1 
and 2) for the 10 accessions. At distance of 4 and 6, cluster 1 had two sub-clusters (I and II), with subcluster I having five (5) accessions, sub-cluster II having four (4) accessions while cluster 2 had only one (1) accession (Figure 2). The five accessions of sub-cluster I had the lowest heights with average seed weights. Accessions NGSA6, NGSA7, NGSA8 and NGSA9 were grouped in the same cluster (all accessions with highest height), with sub-cluster containing accessions with highest seed weights and lowest peduncle lengths. However, the most different accession was NGSA10, the only accession with both the longest terminal leaflet length and peduncle length $(21.56 \mathrm{~cm})$. Characters like plant height, number of leaves, terminal leaflet length, peduncle length and seed weight had very high level of contribution to the total variability observed among the accessions, making these characters important for discriminating among accessions of cowpea. Moreover, for any breeding work to be successful in cowpea, these characters must be considered. This agrees with some of the findings of Vural \& Karasu (2007), Stoilova \& Pereira (2013) on cowpea and Olanrewaju \& Cyril (2012) on Corchorus olitorius. The qualitative traits also grouped NGSA7 and NGSA9 into the same sub-cluster just as they were for quantitative traits, with the same pattern being observed for NGSA4 and NGSA2 both for quantitative and qualitative traits. The level of variations showed by qualitative traits was a bit moderate, as only five traits (growth pattern, plant pigmentation, terminal leaflet shape, pod curvature and leaf colour) out of thirteen studied were able to discriminate effectively among the accessions studied, while the level of similarity for phenotypic expressions among the rest of the traits was very high. Similar results were observed by Selvi et al. (2003).

The variability among the accessions was generally high as observed, and the improvement of this crop is possible through the conventional breedingtechniques (selection and hybridization). It was also observed that the morphological traits had different discriminatory capacity, as some efficiently discriminated than others, making those better traits of choice in plant diversity programs.

This study was able to identify a group of accessions, which are NGSA1, NGSA2, NGSA3, NGSA4, NGSA7, NGSA9 and NGSA 10, which differed from others for number of seeds per pod, pod length, plant height, seed weight, peduncle length and number of pods per plant. They can be selected for better improvement.

Table 1: International Board for Plant Genetic Resources (IBPGR) Cowpea Descriptors

\begin{tabular}{lll}
\hline S/N & Traits & Score and Trait form \\
\hline 1 & Growth pattern & 1, Determinate; 2,Indeterminate \\
2 & Twining tendency & 0, None; 3, Slight; 5, Intermediate; 7, Pronounced \\
3 & Plant pigmentation & 0, None; 1, Very slight; 3, Moderate; 5, Intermediate; \\
& & 7, Extensive; 9, Solid \\
4 & Terminal leaflet shape & 1, Globose; 2, Sub globose; 3, Sub hastate; 4, Hastate \\
5 & Plant hairiness & 3, Glabrescent; 5, Short appressed hairs; 7, Pubescent to hirsute \\
6 & Pod attachment to peduncle & 3, Pendant; 5, 30-90 down from erect; 7, Erect \\
7 & Pod curvature (mature pods) & 0, Straight; 3, Slight curved; 5, Curved; 7, Coiled \\
8 & Immature pod pigmentation & 0, None; 1, Pigmented tip; 2, Pigmented suture; 3, Pigmented \\
& & valves, green sutures; 4, Splashes of pigment; 5, Uniformly \\
& pigmented \\
9 & Seed shape & 1, Kidney; 2, Ovoid; 3, Crowder; 4, Globose; 5, Rhomboid \\
10 & Testa texture & 1, Smooth; 3, Smooth to rough; 5, Rough; 7, Rough to wrinkled; 9, \\
& Wrinkled \\
11 & Splitting of testa & 0, Absent; 1, Present \\
12 & Flower colour & 1, White; 2, Violet; 3, Mauve-pink; 4, Other \\
13 & Leaf colour (Intensity of & 3, Pale green; 5, Intermediate green; 7, Dark green \\
& green) & \\
\hline
\end{tabular}


Table 2: Soil physical and chemical properties during the cowpea growing period

\begin{tabular}{ll}
\hline Parameters & Values \\
\hline $\mathrm{pH}(\mathrm{H} 20)$ & 5.6 \\
Organic C & $2.89 \%$ \\
Org N & $0.14 \%$ \\
Org P & $9.02 \mathrm{mg} / \mathrm{kg}$ \\
org Ca & $6.24 \mathrm{mg} / 100 \mathrm{~g}$ \\
Org Mg & $1.84 \mathrm{mg} / 100 \mathrm{~g}$ \\
$\mathrm{Na}$ & $0.35 \mathrm{mg} / 100 \mathrm{~g}$ \\
$\mathrm{~K}$ & $0.23 \mathrm{mg} / 100 \mathrm{~g}$ \\
$\mathrm{CEC}$ & $8.8 \mathrm{mg} / 100 \mathrm{~g}$ \\
Sand & $89.70 \%$ \\
Silt & $4.20 \%$ \\
Clay & $6.10 \%$ \\
Texture Class & Sandy loam \\
\hline
\end{tabular}

Table 3: Average weather conditions during the cowpea growing period

\begin{tabular}{llccc}
\hline Month & \multicolumn{2}{c}{$\begin{array}{c}\text { Temperature } \\
\left({ }^{\circ} \mathrm{C}\right)\end{array}$} & $\begin{array}{c}\text { Precipitation } \\
(\mathrm{mm})\end{array}$ & $\begin{array}{c}\text { Precipitation } \\
\text { Days }\end{array}$ \\
\hline & Max & Min & & \\
June & 30.9 & 21.6 & 60 & 13 \\
July & 29.1 & 21.3 & 60 & 12 \\
August & 29.1 & 22.1 & 155 & 10 \\
September & 30.1 & 21.1 & 120 & 16 \\
October & 32.3 & 21.3 & 90 & 10 \\
\hline
\end{tabular}


Table 4: Mean Values of the Qualitative Characters

\begin{tabular}{llllllllllllll}
\hline ACCESSIONS & GTP & TWT PTP & TS & PTH & PDA & PDC & IPP & SS & TST & LC & SPT & FLC \\
\hline NGSA1 & 1 & 5 & 1 & 3 & 3 & 5 & 0 & 0 & 1 & 3 & 5 & 0 & 2 \\
NGSA2 & 2 & 3 & 3 & 3 & 3 & 5 & 3 & 0 & 1 & 1 & 5 & 0 & 2 \\
NGSA3 & 2 & 5 & 1 & 2 & 3 & 5 & 3 & 0 & 1 & 3 & 5 & 0 & 2 \\
NGSA4 & 1 & 5 & 1 & 3 & 3 & 5 & 3 & 0 & 1 & 1 & 5 & 0 & 2 \\
NGSA5 & 2 & 5 & 1 & 3 & 3 & 5 & 3 & 0 & 2 & 3 & 7 & 0 & 2 \\
NGSA6 & 2 & 5 & 3 & 3 & 3 & 5 & 3 & 1 & 1 & 3 & 5 & 0 & 2 \\
NGSA7 & 2 & 5 & 5 & 3 & 3 & 3 & 3 & 0 & 1 & 3 & 7 & 0 & 2 \\
NGSA8 & 2 & 5 & 5 & 3 & 3 & 5 & 0 & 0 & 1 & 3 & 7 & 0 & 2 \\
NGSA9 & 1 & 5 & 5 & 3 & 3 & 5 & 3 & 0 & 1 & 3 & 7 & 0 & 2 \\
NGSA10 & 2 & 5 & 1 & 2 & 3 & 5 & 0 & 0 & 1 & 3 & 5 & 0 & 2 \\
\hline
\end{tabular}

GTP, Growth pattern; TWT, Twinning tendency; PTP, Plant pigmentation; TS, Terminal leaflet shape; PTH, Plant hairiness; PDA, Pod attachment to peduncle; PDC, Pod curvature; IPP, Immature pod pigmentation; SS, Seed shape; TST, Testa texture; LC, Leaf colour; SPT, Splitting of testa; FLC, Flower colour

Table 5: Mean Values of the Quantitative Characters

\begin{tabular}{|c|c|c|c|c|c|c|c|c|c|c|c|c|c|}
\hline ACCESSIONS & $\begin{array}{l}\mathrm{PH} \\
(\mathrm{cm})\end{array}$ & NL & $\begin{array}{l}\text { TML } \\
(\mathrm{cm})\end{array}$ & $\begin{array}{l}\text { TMW } \\
(\mathrm{cm})\end{array}$ & $\mathrm{NMB}$ & $\begin{array}{l}\text { PDL } \\
(\mathrm{cm})\end{array}$ & NPP & NNS & NPE & NSP & $\begin{array}{l}\text { PW } \\
(\mathrm{g}) \\
\end{array}$ & $\begin{array}{l}\text { PODL } \\
(\mathrm{cm})\end{array}$ & $\begin{array}{l}100- \\
\text { SW } \\
(\mathrm{g})\end{array}$ \\
\hline NGSA1 & 16.44 & 14.60 & 12.79 & 7.20 & 6.60 & 20.95 & 1.27 & 6.60 & 2.40 & 8.27 & 2.90 & 12.79 & 29.46 \\
\hline NGSA2 & 15.75 & 12.87 & 11.83 & 7.71 & 5.87 & 15.69 & 1.20 & 5.87 & 2.33 & 8.73 & 2.90 & 12.47 & 23.47 \\
\hline NGSA3 & 16.50 & 14.93 & 12.49 & 8.57 & 6.93 & 17.12 & 1.13 & 6.93 & 2.53 & 8.40 & 2.86 & 12.58 & 24.10 \\
\hline NGSA4 & 16.55 & 13.93 & 11.83 & 7.49 & 5.93 & 17.41 & 1.13 & 5.93 & 2.13 & 8.13 & 2.74 & 12.21 & 23.44 \\
\hline NGSA5 & 16.77 & 12.93 & 12.41 & 7.62 & 5.73 & 17.18 & 1.13 & 5.73 & 2.33 & 7.93 & 2.94 & 12.25 & 21.99 \\
\hline NGSA6 & 18.43 & 13.47 & 11.61 & 7.53 & 6.33 & 14.77 & 1.27 & 6.33 & 2.47 & 8.00 & 3.13 & 12.35 & 29.20 \\
\hline NGSA7 & 20.50 & 14.40 & 12.73 & 7.85 & 6.67 & 15.99 & 1.13 & 6.67 & 2.53 & 8.53 & 2.50 & 13.47 & 17.35 \\
\hline NGSA8 & 19.52 & 14.27 & 10.82 & 7.07 & 6.80 & 14.22 & 0.93 & 6.80 & 2.20 & 7.10 & 2.95 & 11.76 & 26.76 \\
\hline NGSA9 & 21.41 & 15.80 & 12.65 & 8.10 & 7.40 & 16.39 & 1.10 & 7.73 & 2.53 & 8.13 & 2.47 & 13.67 & 16.99 \\
\hline NGSA10 & 18.86 & 14.47 & 21.56 & 8.47 & 6.33 & 21.56 & 1.13 & 6.33 & 1.93 & 8.13 & 2.90 & 13.69 & 26.63 \\
\hline
\end{tabular}

PH, Plant height; NL, Number of leaves; TML; Terminal leaflet length; TMW, Terminal leaflet width, NMB, Number of main branches, PDL, Peduncle length; NPP, Number of pods per plant; NNS, Number of nodes on main stem; NPE, Number of pods per peduncle; NSP, Number of seeds per pod; PW, Pod weight; PODL, Pod length; 100-SW, Seed weight. 


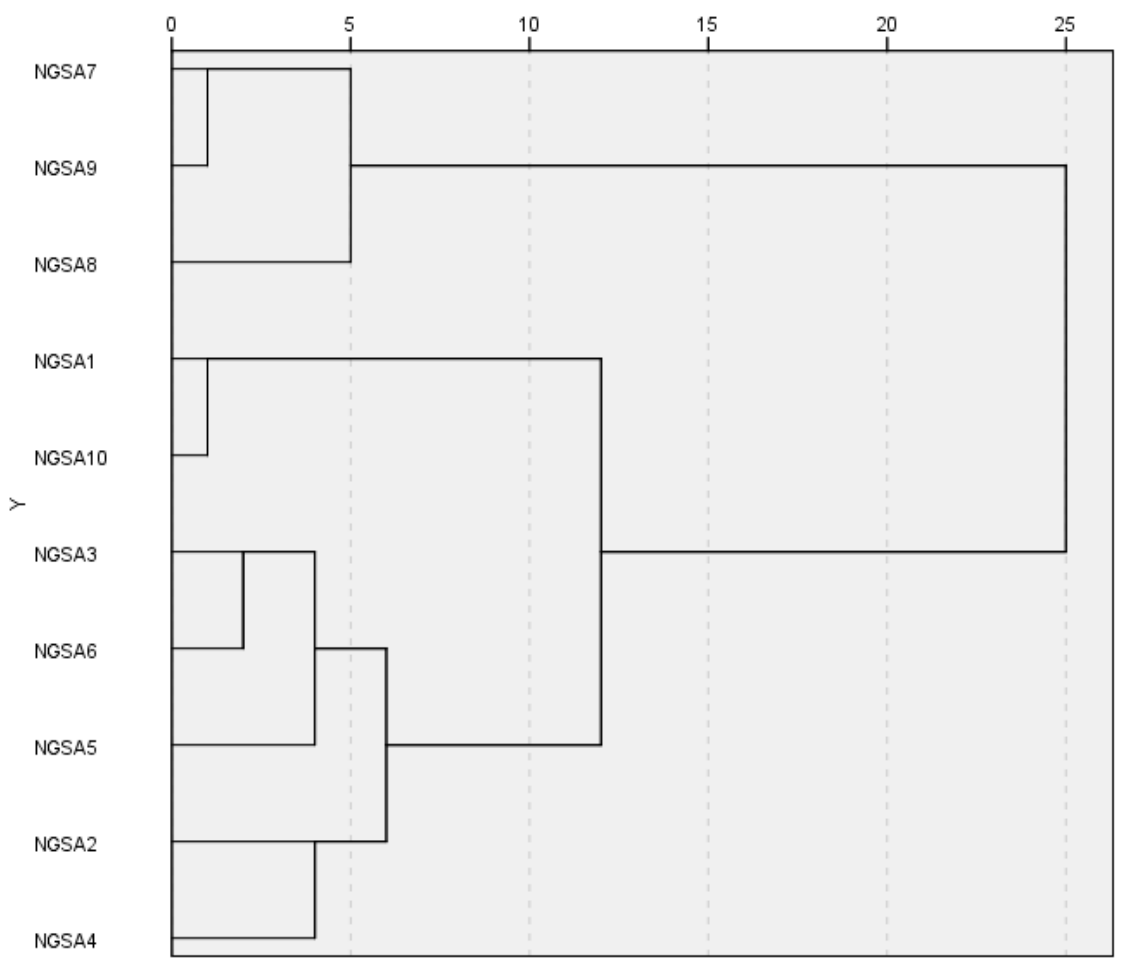

Dendrogram Using Ward Linkage

Figure 1: Positions of the 10 accessions from the qualitative traits

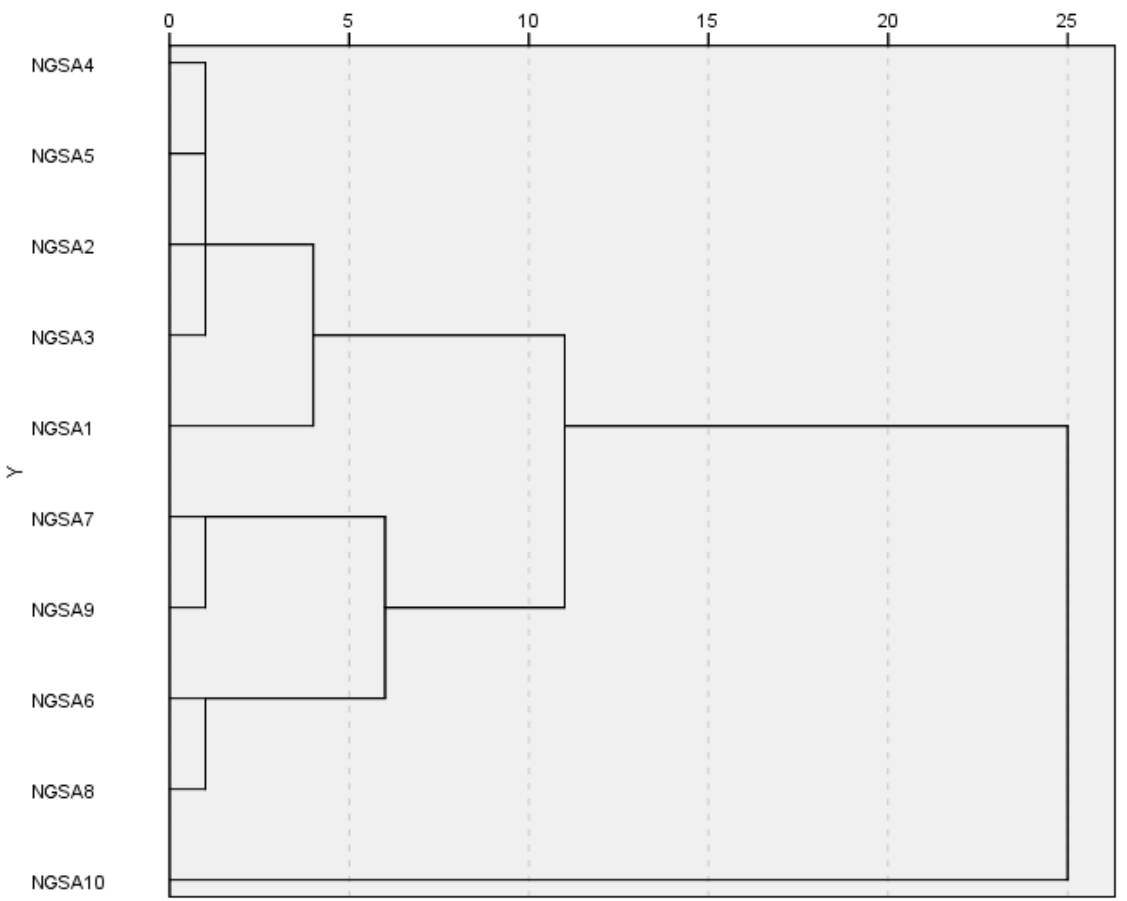

Dendrogram Using Ward Linkage

Figure 2: Positions of the 10 accessions from quantitative traits 


\section{References}

Adetiloye, I.S., Ariyo, O.J., Alake, C.O., Oduwaye, O.O., \& Osewa, S.O. (2013). Genetic diversity of some selected Nigeria cowpea using simple sequence repeats (SSR) marker. Afr. J. Agric. Res. 8(7): 586-590.

Fatokun, C.A., Tarawali, S.A., Singh, B.B., Kormawa, P.M., \& Tamo, M. (2002). Challenges and opportunities for enhancing sustainable cowpea production. Proceedings of the World cowpea conference III, International Institute of Tropical Agriculture (IITA), Ibadan, Nigeria, 4-8 September 2000.

Fawole, O.B., Ahmed, O., \& Balogun, O. (2006). Pathogenicity and cell wall-degrading enzyme activities of some fungi isolates from cowpea (Vigna unguiculata L. Walp). Biokemistri, 18, 45-51.

Knotova, D., Pelikan, J., Vymyslicky, T., \& Hutyrova, H. (2010). Study of variability and similarities among Lotus corniculatus L. accessions. Ratar. Povrt., 47(2), 479-484. Retrieved from http://scindeks.ceon.rs/article.aspx ?artid=1821$39441002479 \mathrm{~K}$

Megloire, N. (2005). The genetic, morphological and physiological evaluation of African cowpea genotypes. University of Free State.

Obute, G.C. (2001). The morphological characterization of an aneuploid Vigna unguiculata (L.). Walp Nigr J Genet \& Breed, 55, 307-311.

Olanrewaju, A.D., \& Cyril, C.N. (2012). Morphological diversity among Corchorus olitorius accessions based on single linkage cluster analysis and principal component analysis. Jordan Journal of Biological Science, 3(5): 191-196.
Pasquet, R.S. (1993). Classification infraspecifique des formes spontanees de Vigna unguiculata (L.) Walp. (Fabaceae) a partir de donnees morphologiques. Bull Jard Bot Belg, 62(1-4), 127. doi: $10.2307 / 3668271$

Sabater, C.R., Alvarez, E.P.C., Iscar, A.M., \& Díez, A.L. (2004). Clustering to reduce regional heterogeneity: A spanish case-study. Journal of Population Research, 21(1), 73-93. doi:10.1007/BF03032211

Selvi, R., Muthiah, A.R., Maheswaran, M., \& Shanmugasundaram, P. (2003). Genetic diversity in the genus Vigna based on morphological traits and isozyme markers. Sabrao J Breeding and Genetics, 35(2), 103-112.

Smith, J.S.C., \& Smith, O.S. (1989). The description and assessment of distance between inbred lines of maize. II. The utility of morphological, biochemical and genetic descriptions and a scheme for testing of distinctiveness between inbred lines. Maydica, 34, 151-161.

Steele, W.M. (1972). Cowpea in Africa. PhD Thesis. University of Reading, United Kingdom. p. 114.

Stoilova, T., \& Pereira, G. (2013). Assessment of genetic diversity in germplasm collection of cowpea (Vigna unguiculata (L.) Walp) using morphological traits. Afr. J. Agric. Res. 8(2): 208-215.

Uarrota, V.G. (2010). Response of cowpea (Vigna unguilata [L. ] Walp) to water stress and phosphorus fertilization.J Agron, 9, 87-91.

Vijayan, S. (2005). Statistical analysis of influence of morphological characters on yield in selected vegetable crops. Dharwad: Dharwad University of Agricultural Sciences.

Vural, H., \& Karasu, A. (2007). Variability studies in cowpea (Vigna unguiculata [L. ] walp.) varieties grown in Isparta, Turkey. Revista UDO Agricola, 7(1), 29-34.

\title{
Tehnika klaster analize upotrebljena za procenu varijabilnosti akcesija vigne (Vigna unguiculata L. Walp) iz Nigerije
}

\author{
Abiola Toyin Ajayi • Adenubi I. Adesoye
}

Sažetak: Genetička varijabilnost između 10 akcesija vigne, Vigna unguiculata (L.) Walp, proučavana je korišćenjem 13 kvalitativnih i 13 kvantitavnih karakteristika. Iz rezultata o kvalitativnim karakteristikama, dendrogram je grupisao 10 akcesija u 2 glavna klastera, 1 i 2 . Klaster 1 je imao 3 akcesije, dok je klaster 2 imao 2 pod-klastera (I i II), gde su postojale 2 akcesije u pod-klasteru I i 5 akcesija u pod-klasteru II. Dendrogram je na osnovu kvantitavnih podataka grupisao 10 akcesija u 2 glavna klastera, 1 i 2 . Na udaljenosti od 4 i 6, klaster 1 je imao 2 pod-klastera (I i II), gde je pod-klaster I imao 5 akcesija, pod-klaster II 4 akcesije, dok je klaster 2 imao samo jednu akcesiju. Pošto je uočeno da su među akcesijama neke karakteristike više diskriminativne od drugih, pre nego što se započne bilo kakav rad na genetičkom diverzitetu, ovo istraživanje je utvrdilo da je neophodna identifikacija pravih agro-morfoloških karakteristika visoko-diskriminativnog kapaciteta. Grupa akcesija kojoj pripadaju NGSA1, NGSA2, NGSA3, NGSA4, NGSA7, NGSA9 i NGSA10, identifikovana je kao drugačija od ostalih po broju semena po mahuni, dužini mahune, visini stabljike, dužini peteljke, težini semena i broju mahuna po biljci. Ove akcesije mogu biti od značaja za program poboljšanja vigne.

Ključne reči: dendrogram, karakteristike, klaster analiza, klasteri, varijabilnost, vigna, Vigna 